\title{
A New Cost in Measuring Investment Performance - Cost of non - Intervention
}

\author{
Andreea-Mariana Manta \\ andreeam.manta@gmail.com \\ Cristina Dima \\ cristina.dima@man.ase.ro \\ Marin Andreica \\ marin.andreica@man.ase.ro
}

The Bucharest University of Economic Studies, Romania

\begin{abstract}
The purpose of this paper is to present a new type of cost that should be taken into consideration in the process of evaluation. The cost proposed improves the accuracy of the final results of this process, concerning the opportunity for implementation of the future investment project. The proposal of the cost was made based on the literature review carried out on the topic of investment project evaluation and on the authors' practical experience as a project evaluator and project manager. The paper's originality is supported by the fact that it brings in a new type of cost in measuring investment projects' performance.
\end{abstract}

Keywords: Cost of non-intervention, Cost - Benefit Analysis, performance, evaluation, project

JEL Code: D61, D62, D81

\section{Introduction}

The present paper suggests a potential solution to improve the relevance of an investment project's evaluation before making the decision of implementing it or not.

In the first two chapters, the article focuses on the present situation of the evaluation process during the pre-implementation stage of the project.

After drawing the conclusions, the next chapter illustrates a new type of cost that would complete the assessment of the future investment project.

\section{Literature Review}

Monitoring and evaluation function was ranked as one of the essential factors that affect the project's success. $[1,2]$

Therefore, as Stem et al. (2005) state " Lack of evaluation framework has a negative effect on the project success" [1, 3]

The evaluation process during the pre-implementation stage of a project is the most important one among all the evaluations carried out through the project's life cycle.

Clarissa C. M. et al. made a remarkable discovery in their qualitative research related to potential problems that would affect the implementation of a health information system (HIS) in Brazil. Their research demonstrated that "problems that usually arise from the implementation and use of nationwide HIS can be anticipated and dealt with beforehand when preimplementation qualitative evaluations are performed". [4]

Kowalski et al. (2018) illustrated in their article entitled "Formative evaluation and adaptation of pre-and early implementation of diabetes shared medical appointments to maximize sustainability and adoption" the critical role and great importance that the preimplementation assessments have during the implementation stage and on the future success or failure of the project. [5]

The table below illustrates an example of sustainability evaluation tool for a road project: 
Table 1 - Sustainability as an ex ante/ex post tool [6]

\begin{tabular}{|c|c|c|}
\hline & ex-ante sustainability evaluation & ex-post sustainability evaluation \\
\hline Project's Stage & Planning & $\begin{array}{l}\text { Operation \& } \\
\text { Maintenance }\end{array}$ \\
\hline Sustainability is part of & $\begin{array}{l}\text { The pre-implementation evaluation } \\
\text { and the decision - making }\end{array}$ & $\begin{array}{l}\text { The monitoring process, for evaluation } \\
\text { purposes }\end{array}$ \\
\hline Sustainability aims at & $\begin{array}{l}\text { Supporting the award of the } \\
\text { alternative option that maximizes } \\
\text { beneficial outcomes on all } \\
\text { perspectives of sustainability }\end{array}$ & $\begin{array}{l}\text { Quantifying sustainable practices associated } \\
\text { with the construction and maintenance } \\
\text { process. In these stages, sustainability can } \\
\text { be useful to evaluate and monitor transport } \\
\text { projects }\end{array}$ \\
\hline $\begin{array}{l}\text { Means by which } \\
\text { sustainability can be used: } \\
\text { A ROAD PROJECT } \\
\text { EXAMPLE }\end{array}$ & $\begin{array}{l}\text { A process where sustainability is } \\
\text { used to provide guidance on } \\
\text { evaluation and decision - making: } \\
\text { i) After identifying project impacts, } \\
\text { calculate the global sustainability } \\
\text { evaluation of each alternative } \\
\text { ii) Obtain the ranking order of } \\
\text { alternatives and select the alternative } \\
\text { with the highest sustainability } \\
\text { performance }\end{array}$ & $\begin{array}{l}\text { Sustainability as a monitoring tool can be } \\
\text { used in different processes to: } \\
\text { i) Evaluate the project in accordance to the } \\
\text { original objectives that it was designed for } \\
\text { ii) Evaluate, compare and select the existing } \\
\text { road, depending on its performance } \\
\text { according to the relevant sustainability } \\
\text { criteria previously defined } \\
\text { iii) Improve current practices in roadway } \\
\text { construction } \\
\text { iv) Suggest best practices and procedures in } \\
\text { the future similar projects. }\end{array}$ \\
\hline
\end{tabular}

Despite the influence that pre-implementation evaluation of investment projects has, there are many cases in which due to the positive results of this evaluation, numerous projects were implemented and demonstrated to be unsustainable. Consequently, pre-implementation evaluation has to be rigorous in order not to waste resources of the project's investor.

In this regard, the paper presents a new type of cost that would improve the accuracy of pre-implementation evaluation, cost of non-intervention. Chapter 4 describes detailed information related to applying this cost in the future project analysis. The following information aims to spot the origins of this new type of cost.

Non-intervention appears in Medicine research. An example of this research paper is entitled "Cost-effectiveness of red blood cell transfusion vs. non-intervention in women with acute anaemia after postpartum haemorrhage", which presents the advantages of applying a nonintervention approach rather than using red blood cells transfusion from an economic point of view. [7]

Another research study entitled "Consequences of Non-Intervention for Infectious Disease in African Great Apes" uses the term of non-intervention aiming to express the limitation of tourist numbers and behaviour among the African Apes in order to avoid increasing the level of disease threats to the apes. In this case, non-intervention of tourists is associated with the potential loss of revenue provided by them. [8]

In the Climate Change related article "Uncertainty and risk in climate projections for the 21st century: comparing mitigation to non-intervention scenarios", the term illustrates the scenario of non-intervention on the climate change over the period $2000-2100$ in comparison with the mitigation scenario concerning the costs associated to them. [9]

In addition, the same term is used in the policy studies such as "The Cost of Doing Nothing" where it is associated with the non-intervention policy adopted by UK during humanitarian crises as the one in Rwanda or the one in Bosnia. In these cases, the cost of nonintervention is assimilated with the number of people that died during the conflicts. [10] 
Moreover, a potential synonym of the cost of non-intervention appears in a study conducted by The World Bank, Global Development Finance respectively cost of noninvestment, which refers to the investment and non-investment-grade securities fluctuation. [11]

In Neuroeconomics research studies non-investment appears when the brain center for risk (Insula) is activated and limits the activity of the Nucleus Accumbes, which is Center for Pleasure. In addition, these studies stress the influence that our emotions have when making investment decision and suggest that emotions like greed are usually responsible when investors are prone to make impulsive decisions. [12]

This fact can be the reason for not taking into consideration the cost of non-intervention in pre-implementation evaluation of an investment project.

Another referance of cost of non-investment is made in the handbook 1995 "Life - cycle costing manual for Federal Energy Management Program prepared for U.S. Departament of Energy" and is assimilated with the "costs related to the use of a building or building system, including energy and water costs." [13]

Pia A. utilised the term cost of non-investment within her paper "Is it Time to Integrate Non-investment Concerns into International Investment Law?" in order to refer to protection of aspects such as human rights and environment. [14]

Table 2 - Cost of non-intervention and Cost of non-investment

\begin{tabular}{ll} 
Terms & \multicolumn{1}{c}{ Meaning } \\
Non-intervention & $\begin{array}{l}\text { Not applying a medical intervention } \\
\text { Restricting tourists to access a certain area } \\
\text { Not interfering in the climate change }\end{array}$ \\
& Not intervening in a conflict/war \\
Trend towards not investing
\end{tabular}

All in all, according to the literature review shortly exposed above the terms cost of nonintervention and cost of non-investment have different meanings and are used in various contexts and domains. Hence, for the completion of pre-implementation analysis of projects we chose to use the term cost of non-intervention to avoid the confusion that can be made with the financial term cost of non-investment that signifies a limit beyond which is not recommended to invest in securities.

\section{Cost - Benefit Analysis}

The paper includes the present chapter dedicated to the Cost-Benefit Analysis because we consider it the most common type of method used during the pre-implementation stage of investment projects. Therefore, the chapter highlights the main characteristics of the CostBenefit Analysis.

The Cost-Benefit Analysis was initially developed in 1920, in "Economics of Welfare" by Pigou. The writing defined the "divergence of social and private costs and the new welfare economics". [15]

Firstly in the USA, the Cost-Benefit Analysis was introduced by the Flood Control Act, in the 1936, which mentiones about the "the interests of general welfare" [16]

The main stages of Cost-Benefit Analysis are illustrated in the following tabel:

Table nr. 3 - Stages of CBA [17]

\begin{tabular}{|l|l|}
\hline \multicolumn{1}{|c|}{ Stages } & \multicolumn{1}{|c|}{ Cost-Benefit Analysis } \\
\hline Outlining the context & $\begin{array}{l}\text { The context is described from social, political, } \\
\text { environmental, economic and institutional }\end{array}$ \\
\hline
\end{tabular}




\begin{tabular}{|c|c|}
\hline & $\begin{array}{l}\text { point of view. In this stage, the main } \\
\text { information refers to: present situation in the } \\
\text { region of implementation related to labour } \\
\text { market, level of GDP, demographic } \\
\text { fluctuation, policies and development } \\
\text { strategies in the domain in which the project } \\
\text { will be implemented, service provision, value } \\
\text { of costs involved, statistics, population's } \\
\text { expectation etc. }\end{array}$ \\
\hline Setting the objectives & $\begin{array}{l}\text { The objectives have to be set in accordance } \\
\text { with the project's needs so that they can be } \\
\text { evaluated using indicators and target values. } \\
\text { The objectives have to convey to the } \\
\text { operational programme, national policies and } \\
\text { strategies. }\end{array}$ \\
\hline Identifying the project & $\begin{array}{l}\text { Choosing the name of the project according } \\
\text { with its scope }\end{array}$ \\
\hline $\begin{array}{l}\text { Study of feasibility/Techical } \\
\text { feasibility }\end{array}$ & $\begin{array}{l}\text { In this stage there are carried out an analysis } \\
\text { on the existing demand for the } \\
\text { products/services provided by the project, } \\
\text { analysis on the existing alternatives, change in } \\
\text { environmental aspects, technical design, } \\
\text { estimation of costs, and the Gantt for } \\
\text { implementation of the project }\end{array}$ \\
\hline Financial analysis & $\begin{array}{l}\text { This analysis contains an estimation of the } \\
\text { profitability of the project, future cash-flow } \\
\text { which take into consideration the benefits and } \\
\text { the costs of the project and a forecast for the } \\
\text { sustainability of the project. }\end{array}$ \\
\hline Economic analysis & $\begin{array}{l}\text { If the financial analysis's results indicate a } \\
\text { negative NPV(Net Present Value), then an } \\
\text { economic analysis is applied and this type of } \\
\text { analysis takes into consideration the impacts } \\
\text { that are not related to the market. }\end{array}$ \\
\hline Risk analysis & $\begin{array}{l}\text { It implies an assessment of different scenarios } \\
\text { of } \\
\text { the project, identifying the risk, asigning } \\
\text { probabilities to the risks, establishing the } \\
\text { measures for prevention, elimination and } \\
\text { mitigaton of the risks. }\end{array}$ \\
\hline
\end{tabular}

One of the most critical flaws identified in applying Cost-Benefit Analysis in order to evaluate the future performance of a project in the pre-implementation stage is represented by incomplete categories of costs included in the economic analysis. This leads to unrealistic results and can erroneously influence the decision to implement a certain project. 


\section{Cost of non-intervention}

The cost of non-intervention proposed in the present paper will contain the cost of losing the potential benefits provided by the scenario in which the project would be implemented. The following table contains several examples of potential costs of non-intervention:

Table 4 - Costs of Non-Intervention

\begin{tabular}{|l|l|}
\hline \multicolumn{1}{|c|}{$\begin{array}{c}\text { Projects' } \\
\text { Field }\end{array}$} & \multicolumn{1}{c|}{ Examples of Cost of Non-Intervention } \\
\hline $\begin{array}{l}\text { Public } \\
\text { Transport }\end{array}$ & $\begin{array}{l}\text { Average taxes paid by a person throughout his life x number of lives lost due to } \\
\text { lack of project implementation - construction of a highway }\end{array}$ \\
\hline Health & $\begin{array}{l}\text { Health insurances paid to suffering persons because of the lack of medical } \\
\text { services in the area x number of suffering persons }\end{array}$ \\
\hline Education & $\begin{array}{l}\text { Social assistance funds x number of persons that did not graduate school } \\
\text { Unemployment benefits x number of persons that did not graduate a proper } \\
\text { level of education }\end{array}$ \\
\hline Environment & $\begin{array}{l}\text { Taxes paid by a person throught his life x number of deaths due to pollution } \\
\text { problems } \\
\text { Health insurances paid to suffering persons because of the pollution problems } \mathrm{x}\end{array}$ \\
\hline
\end{tabular}

Considering the cost of non-intervetion would complete the image offered by the CostBenefit Analysis with all types of costs that should be considered in order to obtain relevant results related to the future success or failure of the future project.

\section{Research methods and principles}

The type of cost presented was proposed using the extrapolation of "non-intervention" term used in other domains presented in the chapter entitled Literature Review. Therefore, the first method used in developing this solution was extrapolation.

The second method applied was the review of research papers in which the terms "nonintervention" and "non-investment" appear. Hence, I studied over 30 scientific papers in order to extract the meanings of the terms.

The idea of proposing a new type of cost is based on the authors' professional experience as project evaluators, project elaborators and a project managers.

\section{Conclusion}

The introduction of the cost of non-intervention in the analysis would be the first step to improve the present methodological framework of investment projects' performance evaluation. It represents a cost that has not been taken into consideration so far and would contribute to make a more accurate decision in connection with the implementation of the future project.

\section{References}

[1] Kamau C.G., Humam B. M., Efficacy of Monitoring and Evaluation Function in Achieving Project Success in Kenya: A Conceptual Framework, Science Journal of Business and Management, Volume 3, Issue 3, June 2015, Pages: 82-94, available at: http:/ / article.sciencepublishinggroup.com/ html/10.11648.j.sjbm.20150303.14.html accessed: 10.05.2019 [2] Ika, L. A., Diallo, A., \& Thuillier, D. (2012). Critical success factors for World Bank projects: an empirical investigation. International Journal of Project Management, 30(1), 105-116, Crossref 
[3] Stem, C., Margoluis, R., Salafsky, N., \& Brown, M. (2005). Monitoring and evaluation in conservation: a review of trends and approaches. Conservation Biology, 19(2), 295-309, Crossref

[4] Mussi C. C., Pereira, C.D.D.V., Lacerda R. T. D. O., Marques E. D. S., Pre-Implementation evaluation of a nationwide information system for university hospitals: lessons learned from a study in Brazil , Journal Behaviour \& Information Technology, Volume 37, 2018 - Issue 3, available at: bttps:/ / www.tandfonline.com/doi/full/ 10.1080/0144929X.2018.1430850?scroll=top\&oneedAccess=true, https:/ / doi.org/10.1080/0144929X.2018.1430850, accessed: 10.05.2019

[5] Kowalski C. P., Veeser M., Heisler M., Formative evaluation and adaptation of pre-and early implementation of diabetes shared medical appointments to maximize sustainability and adoption, BMC Family Practice (2018), available at: https: / bmcfampract.biomedcentral.com/track/pdf/10.1186/s12875-018-07973, https:/ / doi.org/10.1186/s12875-018-0797-3, accessed: 10.05.2019

[6] Bueno P.C., Vassallo J.M.,Cheung K., Sustainability Assessment of Transport Infrastructure Projects: A Review of Existing Tools and Methods, Biblioteca de la Universidad Politécnica de Madrid, work financed by European Investment Bank, 2015, available at: bttp:// oa.upm.es/46364/1/INVE_MEM_2015_256408.pdf accessed: 10.05.2019

[7] Prick B. W., Duvekot J. J., van der Moer P. E., van Gemund, N., van der Salm P. C. M., Jansen A. J. G., van Rhenen D. J., Mol B. W., Uyl-de Groot, C. A., Cost-effectiveness of red blood cell transfusion vs. non-intervention in women with acute anaemia after postpartum haemorrhage, Vox Sanguinis Volume 107, Issue 4, November 2014, Pages 381-388, available at: bttps:/ / onlinelibrary.wiley.com/doi/full/10.1111/vox.12181 accessed: 10.05.2019

[8] Sadie J. R., Peter D. W., Consequences of Non-Intervention for Infectious Disease in African Great Apes, PLoS ONE 6(12): e29030, December 2011, Volume 6, Issue 12, doi:10.1371/ journal.pone.0029030, available

https://journals.plos.org/plosone/article/file?id=10.1371/journal.pone.0029030\&type=printable $\quad$ accessed: 10.05.2019

[9] Tomassini L., Knutti R., Plattner G. K., van Vuuren D. P., Stocker T. F., Howarth R. B., Borsuk. M. E., Uncertainty and risk in climate projections for the 21st century: comparing mitigation to non-intervention scenarios, Climatic Change, December 2010, Volume 103, Issue 3-4, pp 399-422, available at: bttps:/ / link.springer.com/article/10.1007/s10584-009-9763-3 accessed: 10.05.2019

[10] Cox J. MP (1974-2016), Tugendhat T. MP, Completed by McGovern A. MP and Tugendhat T. MP, The Cost of Doing Nothing. The price of inaction in the face of mass atrocities, Published by Policy Exchange, 8 10 Great George Street, Westminster, London SW1P 3AE, ISBN: 978-1-910812-26-6, 2017, available at: https://policyexchange.org.uk/ wp-content/uploads/2017/01/Intervention-01-17_v8.pdf, accessed: 10.05.2019 [11] Staff of the International Bank, for Reconstruction and Development/ The World Bank, Global Development Finance, The Role of International Banking, ISBN: $978-0-8213-7388-0$, doi: 10.1596/978-0-8213-7388-0, 2008, available at:

bttps:/ / books.google.ro/ books?id $=L B 7 ₹ 0 K k 3 Y O M C \Theta p g=P A 63 \& / p g=P A 63 \& d q=$ cost + of + non investmentesource $=$ bleots $=u T_{2} 0 \%$ -

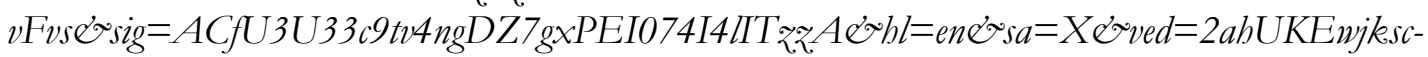
060_iAbVEposKHRifAz8Q6 AEwD3oECAgQAQ\#v=onepage 2 q $=$ cost\%200\%20noninvestmenteof=false, accessed: 10.05.2019

[12] Ana Njegovanovic, Neurological aspects of finance, transmitters, emotions, mirror neuronal activity in financial decision, Marketing and Management of Innovations, 2018, Issue 3, available at: http://mmi.fem.sumdu.edu.ua/sites/default/files/MMI_A61-03-2018_Njegovanovic.pdf，ａccessed: 10.05.2019

[13] Fuller S. K, Petersen S. R., Life-Cycle Costing Manual for the Federal Energy Management Program, Prepared for US Departament of Energy, 1995 Edition, available at: https:/ / books.google.ro/books?id=mQg6_dVvsLcC\&pg=SL201-PA4\&/pg=SL201-

$P A 4 \Theta d q=$ cost + of + non-

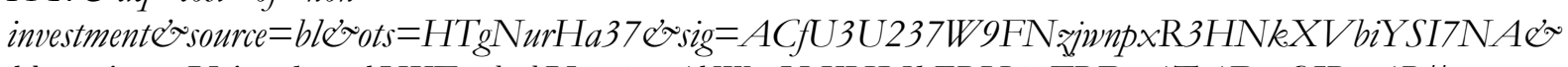
$b l=e n \& s a=X \& v e d=2 a b U K E w j b 6 b X 864 \_i A b W w t Y$ sKHV kZBH44FBDoATADegQIB $\times A B \# v=$ onep age $\delta q=\cos t \% 20 \% \%$ 20 non-investmenteof=true, accessed: 10.05.2019 
[14] Acconci P., Is it Time to Integrate Non-investment Concerns into International Investment Law? "Aligning Human

Rights and Investment Protection" TDM Special, ISSN : 1875-4120, Issue : Vol. 10, issue 1, Published:

January 2013, available at: https:/ / wmw.academia.edu/6832233/Is_it_Time_to_Integrate_Noninvestment_Concerns_into_International_Investment_Law, accessed: 10.05.2019

[15] Cost-Benefit Analysis and the Environment Recent Developments, ISBN 92-64-01004-1, OECD 2006 available at: http:// www.oecd.org/environment/tools-evaluation/36190261.pdf, accessed: 10.05.2019

[16] Pearce D. W., The Origins of Cost-Benefit Analysis, Part of the Studies in Economics book series, Palgrave, London (1983), available at: https:// link.springer.com/chapter/10.1007\%2F978-1-349-171965_2, accessed: 10.05.2019

[17] Guide to Cost-Benefit Analysis of Investment Projects, Economic appraisal tool for Cohesion Policy 2014 - 2020, December 2014, European Commission, available at: bttps:/ / ec.europa.eu/regional_policy/sources/docgener/studies/pdf/cba_guide.pdf, accessed: 10.05.2019 